\title{
Bioaffinity Sensor Based on Nanoarchitectonic Films: Control of the Specific Adsorption of Proteins through the Dual Role of an Ethylene Oxide Spacer
}

Johanna Davila, ${ }^{\dagger}$ Delphine Toulemon, ${ }^{\dagger}$ Tony Garnier, ${ }^{\dagger}$, Aurélie Garnier, $^{\dagger}$ Bernard Senger,, ,॥

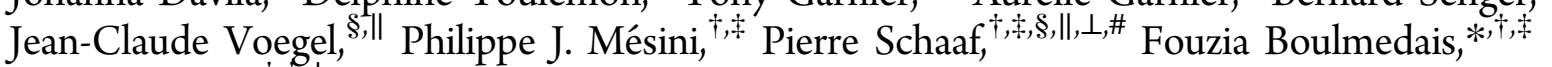
and Loïc Jierry ${ }^{\dagger,+, \perp}$

${ }^{\dagger}$ Centre National de la Recherche Scientifique, Unité Propre de Recherche 22, Institut Charles Sadron, 23 rue du Loess, BP 84047, 67034 Strasbourg Cedex 2, France

${ }^{\ddagger}$ International Center for Frontier Research in Chemistry, 8 allée Gaspard Monge, 67000 Strasbourg, France

${ }^{\S}$ Institut National de la Santé et de la Recherche Médicale, Unité 1121, 11 rue Humann, 67085 Strasbourg Cedex, France

"Faculté de Chirurgie Dentaire, Université de Strasbourg, 1 Place de l'Hôpital, 67000 Strasbourg, France

${ }^{\perp}$ Ecole de Chimie, Polymères et Matériaux, 25 rue Becquerel, 67087 Strasbourg Cedex 2, France

${ }^{\#}$ Institut Universitaire de France, 103 Boulevard Saint-Michel, 75005 Paris, France

Supporting Information

ABSTRACT: The identification and quantification of biomarkers or proteins is a real challenge in allowing the early detection of diseases. The functionalization of the biosensor surface has to be properly designed to prevent nonspecific interactions and to detect the biomolecule of interest specifically. A multilayered nanoarchitecture, based on polyelectrolyte multilayers (PEM) and the sequential immobilization of streptavidin and a biotinylated antibody, was elaborated as a promising platform for the label-free sensing of targeted proteins. We choose ovalbumin as an example. Thanks to the versatility of PEM films, the platform was built on two types of
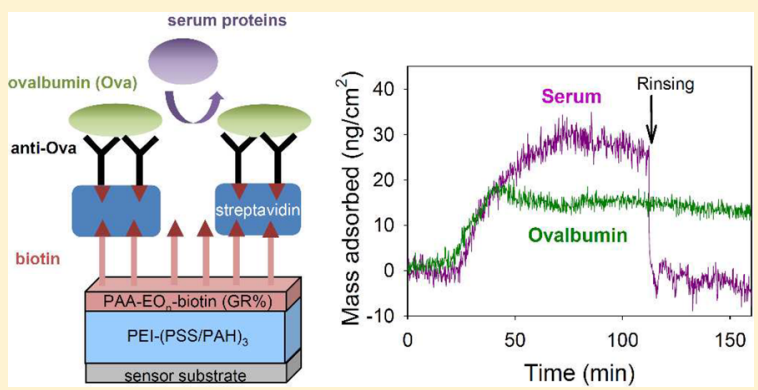
sensor surface and was evaluated using both optical- and viscoelasticbased techniques, namely, optical waveguide lightmode spectroscopy and the quartz crystal microbalance, respectively. A library of biotinylated poly(acrylic acids) (PAAs) was synthesized by grafting biotin moieties at different grafting ratios (GR). The biotin moieties were linked to the PAA chains through ethylene oxide (EO) spacers of different lengths. The adsorption of the PAA$\mathrm{EO}_{n}$-biotin (GR) layer on a PEM precursor film allows tuning the surface density in biotin and thus the streptavidin adsorption mainly through the grafting ratio. The nonspecific adsorption of serum was reduced and even suppressed depending on the length of the $\mathrm{EO}$ arms. We showed that to obtain an antifouling polyelectrolyte the grafting of $\mathrm{EO}_{9}$ or $\mathrm{EO}_{19}$ chains at $25 \%$ in $\mathrm{GR}$ is sufficient. Thus, the spacer has a dual role: ensuring the antifouling property and allowing the accessibility of biotin moieties. Finally, an optimized platform based on the PAA-EO 9 -biotin (25\%)/streptavidin/biotinylated-antibody architecture was built and demonstrated promising performance as interface architecture for bioaffinity sensing of a targeted protein, in our case, ovalbumin.

\section{INTRODUCTION}

The identification and quantification of biomarkers and proteins are important issues that allow the early detection of diseases. ${ }^{1,2}$ Present at low concentrations in complex body fluids (e.g., serum, plasma, and urine), ${ }^{3}$ biomarkers have to be detected specifically and in a reproducible manner through biosensors. Nonspecific protein binding from plasma or serum constitutes one of the limitations of biosensors. ${ }^{4}$ Antifouling surfaces able to bind target molecules specifically are required for the development of biosensing platforms based on surfacesensitive analytical techniques. Label-free technology for biodetection is a current field of research that is commonly based on changes in optical or viscoelastic properties at the sensor/biological fluid interface caused by the binding of biomolecules. ${ }^{5}$ Optical sensing has been extensively used for drug screening for many years on the basis of surface plasmon resonance $(\mathrm{SPR})^{6,7}$ or optical waveguide light-mode spectroscopy (OWLS). ${ }^{8}$ The quartz crystal microbalance (QCM), based on viscoelastic changes, is less used as a biosensor even if

Special Issue: Interfacial Nanoarchitectonics

Received: November 15, 2012

Revised: January 24, 2013

Published: January 24, 2013 
recent studies show interest in this technique over optical sensing. ${ }^{9-11}$

The functionalization of the sensor surface thus has to be designed properly to prevent nonspecific interactions and to detect the biomolecule of interest specifically. The development of surface coatings that prevent protein adsorption has received considerable attention over the past few decades. The most common synthetic material used is ethylene oxide $\left(\mathrm{CH}_{2}-\right.$ $\mathrm{CH}_{2} \mathrm{O}$, EO), also named ethylene glycol (EG). The effectiveness of poly(ethylene oxide) (PEO) in resisting protein adsorption is related to four of its properties: PEO is hydrophilic, electrically neutral, a hydrogen bond acceptor, and not a hydrogen bond donor. ${ }^{12}$ Other ways have been developed to obtain protein-resistant surfaces. Self-assembled monolayers (SAMs) presenting mannitol groups ${ }^{13}$ were found to be resistant to protein adsorption. Following the discovery that the predominant presence of phosphorylcholine (PC) moieties is responsible for the nonthrombogenic character of erythrocyte membranes, ${ }^{14}$ surfaces-bearing PC groups were developed. Because of the zwitterionic character of PC, these surfaces proved to be highly protein-resistant. ${ }^{15}$ Antifouling materials based on EO or PC were either brought onto the surface through SAMs, ${ }^{16,17}$ grafted onto the surface, ${ }^{18,19}$ or grafted onto polyelectrolytes, ${ }^{20,21}$ which are subsequently adsorbed as a monolayer ${ }^{22,23}$ or as part of polyelectrolyte multilayer (PEM) films. ${ }^{24}$ SAMs that require a gold substrate and the grafting of antifouling molecules, performed mainly on silicon or silicium substrate, ${ }^{25}$ are suitable only for sensing techniques compatible with such substrates. Antifouling groups brought onto the surface by the electrostatic adsorption of polyelectrolytes bearing these groups as side chains allow this drawback to be overcome. ${ }^{24,26-29}$ PEM, obtained by the alternate deposition of cationic and anionic polymers, emerged as a simple approach to functionalizing surfaces. ${ }^{30}$ Such films find wide application in chemical and biological detection, ${ }^{31,32}$ biotechnology, ${ }^{33-35}$ and biomaterials. ${ }^{36,37}$ Proteins, ${ }^{38}$ enzymes, ${ }^{39}$ peptides, ${ }^{40}$ DNA $^{41}$ and drugs ${ }^{42}$ can be embedded in the architecture of thin films, maintaining a secondary structure close to that of their native form as well as their bioactivity. ${ }^{43}$ These features made the PEM films a powerful polyvalent tool for surface engineering.

Besides the antifouling properties of the surface, a specific interaction is needed for the development of a sensitive biosensor. Biotin and streptavidin present one of the strongest and most stable noncovalent specific interactions. During the past decade, the streptavidin-biotin system has become a commercially available tool for research as well as medical and industrial applications. ${ }^{44}$ The strepavidin-biotin complex is used for affinity-based immunoassays and diagnostics. Various biotinylated biomacromolecules (such as antigens) are thus commercially available. This wide range of applications makes biotinylated sensor surfaces attractive for almost all label-free sensing techniques. Using a biotinylated poly(L-lysine)-gpoly(ethylene glycol) (PLL-g-PEG/PEGbiotin) monolayer and streptavidin, Huang et al. immobilized biotinylated antirabbit immunoglobulin to bind rabbit immunoglobulin. The biotin concentration at the interface was controlled by forming mixed layers of PLL-g-PEG/PEGbiotin and PLL- $g$ PEG using a solution mixture containing both polymers in different ratios. 8

The aim of this study was to elaborate multilayered nanoarchitectures using PEM on the basis of a library of biotinylated poly(acrylic acid) (PAA), synthesized with differ- ent grafting ratios $(\mathrm{GR}=1,5,10$, or $25 \%)$ and with different EO oligomers $\left(\mathrm{EO}_{n}\right)$ of arms with $n=0,3,9$ and 19, named PAA-EO ${ }_{n}$-biotin (GR). These nanoarchitectures were studied as biosensor platforms for label-free sensing using two analytical techniques (QCM and OWLS). The sensitivities of the OWLS and QCM techniques are about $1 \mathrm{ng} / \mathrm{cm}^{2}$. The versatility of PEM films allows the functionalization of all kinds of sensor surfaces (here, the gold surface of QCM crystals and the $\mathrm{Si}_{0.8} \mathrm{Ti}_{0.2} \mathrm{O}_{2}$ surface of OWLS chips). To functionalize the

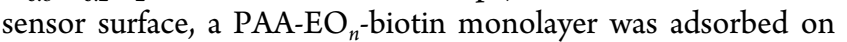
top of a poly(styrene sulfonate)/poly(allylamine hydrochloride) (PSS/PAH) precursor multilayer to become substrateindependent. A double role is expected for the $\mathrm{EO}_{n}$ spacers: First, they are arms that keep the biotin groups away from the multilayer, thereby rendering them more accessible to the environment. Second, according to their length and their grafting ratio on PAA, EO spacers also play the role of antifouling groups. This original strategy, based on the dual property of biotinylated $\mathrm{EO}_{n}$ arms, leads to the design of a film that is able to recognize streptavidin specifically among other serum proteins through only one kind of modification along the PAA (Scheme 1a). Finally, we show that such a platform can be

Scheme 1. Schematic Representation of the Immunoassay Platform $^{a}$

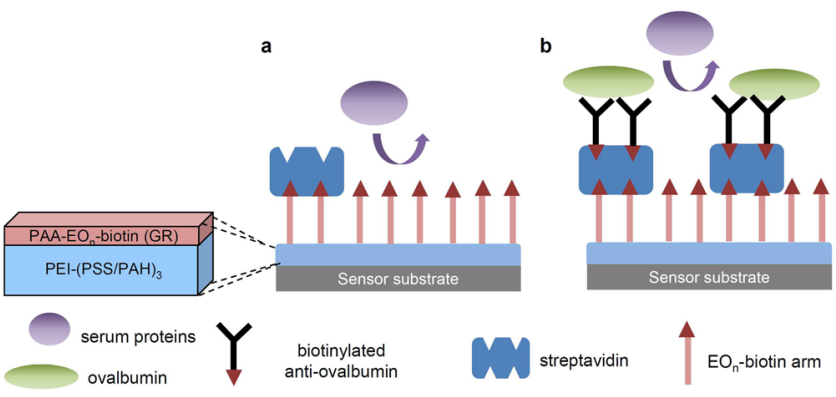

${ }^{a_{T}}$ This platform is based on a $\mathrm{PEI} /(\mathrm{PSS} / \mathrm{PAH})_{3}$ precursor film followed by the sequential adsorption of (a) $\mathrm{PAA}-\mathrm{EO}_{n}$-biotin and streptavidin, followed by (b) biotinylated antiovalbumin. (a) The PAA-EO ${ }_{n}$-biotin surface resists the nonspecific adsorption of serum proteins, and the biotinylated EO arms specifically adsorb streptavidin. (b) Biotinylated antiovalbumin binds to streptavidin and acts as a capture molecule towards ovalbumin through antibody-antigen interactions while still suppressing the nonspecific adsorption of serum proteins.

used to build a bioaffinity sensing surface that specifically recognizes an antigen through the immobilization of its biotinylated antibody. As a model immunoassay, we choose to bind ovalbumin using a biotinylated antiovalbumin antibody (Scheme 1b).

\section{MATERIAL AND METHODS}

Materials. Poly(ethylene imine) (PEI, Sigma, MW $750000 \mathrm{~g} /$ mol), poly(allylamine hydrochloride) (PAH, Aldrich, MW $15000 \mathrm{~g} /$ mol), poly(sodium 4-styrenesulfonate) (PSS, Aldrich, MW $70000 \mathrm{~g} /$ $\mathrm{mol}$ ), and poly(acrylic acid) (PAA, Aldrich, 35 wt \% in water, MW $100000 \mathrm{~g} / \mathrm{mol}$ ) were used as received. The polyelectrolytes were dissolved at $0.5 \mathrm{mg} / \mathrm{mL}$ in Tris- $\mathrm{NaCl}$ buffer, prepared from trizma hydrochloride (Sigma, $\geq 99 \%$ ) at $20 \mathrm{mM}$ and $\mathrm{NaCl}$ (Sigma, $\geq 99.5 \%$ ) at $0.15 \mathrm{M}$ in Milli-Q water, adjusted to $\mathrm{pH} 7.4$ just before use. The biotinylated PAA was dissolved at $0.5 \mathrm{mg} / \mathrm{mL}$ in Tris- $\mathrm{NaCl}$ buffer. Fetal bovine serum (FBS, Gibco), ovalbumin (Sigma, MW $45000 \mathrm{~g} /$ $\mathrm{mol}$ ), and streptavidin (Sigma, S4762, MW $60000 \mathrm{~g} / \mathrm{mol}$ ) were prepared in Tris- $\mathrm{NaCl}$ buffer for the adsorption tests. Biotinylated- 


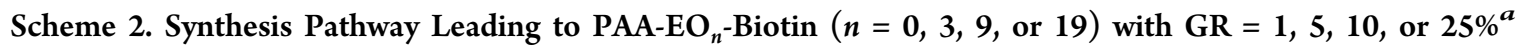

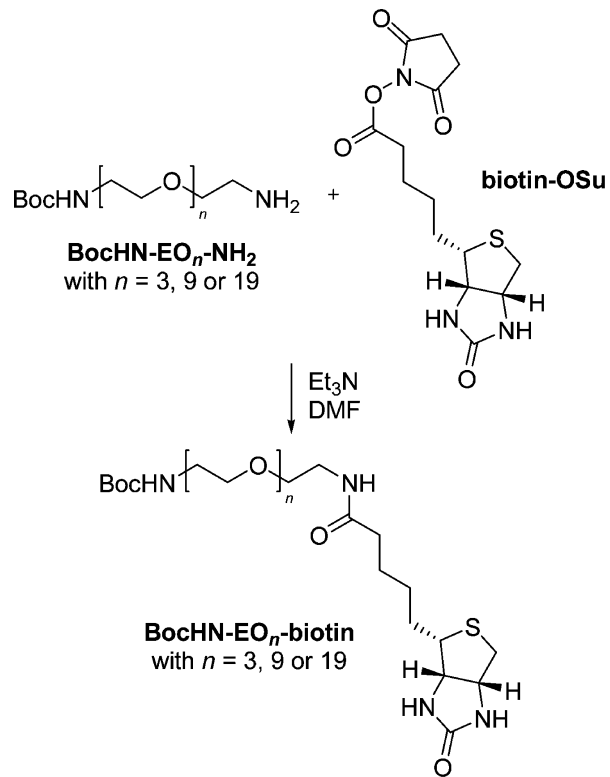

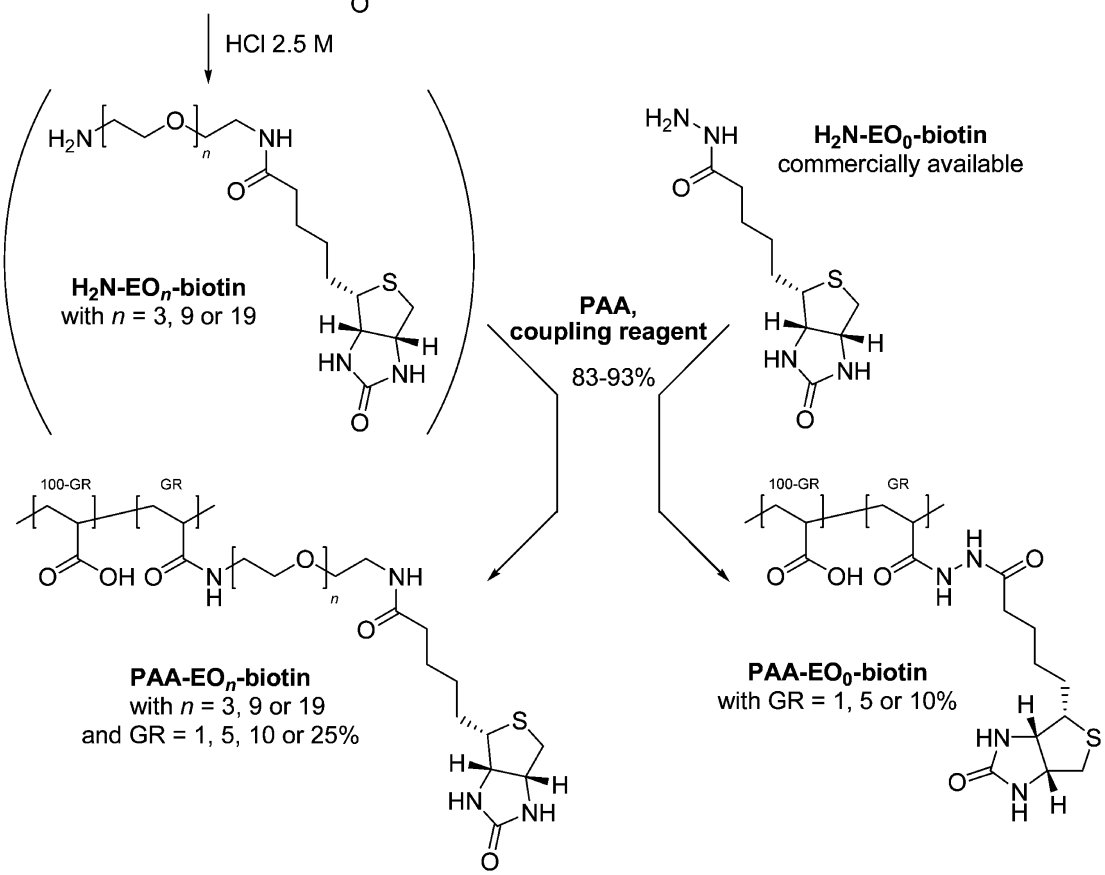

$a_{\text {The }} \mathrm{H}_{2} \mathrm{~N}-\mathrm{EO}_{n}$-biotin intermediates depicted in parentheses were not isolated.

antiovalbumin antibody (rabbit polyclonal immunoglobulin to ovalbumin, ab8389, MW $150000 \mathrm{~g} / \mathrm{mol}$ ) was purchased by Abcam (Paris, France) and diluted at $25 \mu \mathrm{g} / \mathrm{mL}$ in Tris- $\mathrm{NaCl}$ buffer.

Preparation of Biotin-Grafted PAA. PAA-EO ${ }_{n}$-biotin with $n=0$, 3,9 , or 19 and GR $=1,5,10$, or $25 \%$ as depicted in Scheme 2 have been prepared according to the procedures described in the Supporting Information (SI).

OWLS Measurements. Optical waveguide light-mode spectroscopy (OWLS) was performed on an OWLS 120 (Microvacuum, Budapest, Hungary) using OW2400 waveguides made of $\mathrm{Si}_{0.8} \mathrm{Ti}_{0.2} \mathrm{O}_{2}$ (Microvacuum, Budapest, Hungary). The technique has been extensively described elsewhere ${ }^{45}$ and experimentally applied to polyelectrolyte multilayers ${ }^{46,47}$ and to protein adsorption. ${ }^{48}$ In brief, a laser beam shines on a grating imprinted in the waveguide, and one determines the incoupling angles for both the transverse electric (TE) and the transverse magnetic (TM) waves into the guide. Each incoupling angle corresponds to an effective refractive index, $N_{\mathrm{TE}}$ and $N_{\mathrm{TM}}$, respectively. From these effective refractive indices, the refractive index, $n_{\text {OWLS }}$, the optical thickness, $d_{\text {OWLS }}(\mathrm{nm})$, and the optical mass of an adsorbed layer, Qowls $(\mathrm{nm})$, can be obtained with the homogeneous and isotropic monolayer model knowing the refractive index of the buffer $\left(n_{\mathrm{C}}\right)$ :

$$
Q_{\text {OWLS }}=\left(n_{\text {OWLS }}-n_{\mathrm{C}}\right) \times d_{\text {OWLS }}
$$

The adsorbed mass $q_{\text {OwLS }}\left(\mathrm{ng} / \mathrm{cm}^{2}\right)$ is calculated from the optical mass using the refractive index increment $\mathrm{d} n / \mathrm{d} c\left(\mathrm{~cm}^{3} / \mathrm{g}\right)$ :

$$
q_{\mathrm{OWLS}}=\frac{Q_{\mathrm{OWLS}} \times 100}{\mathrm{~d} n / \mathrm{d} c}
$$

The $\mathrm{d} n / \mathrm{d} c$ values of the different biotinylated PAAs were determined in Tris- $\mathrm{NaCl}$ buffer as follows: five solutions with concentrations $c$ ranging from 0.3 to $2.0 \mathrm{mg} / \mathrm{mL}$ were prepared, and the refractive indices $n$ were determined using an RFM 340 refractometer (Bellingham-Stanley, England). For each polymer tested, the $R^{2}$ value of the linear regression of $n$ versus $c$ was about 0.999 . The 

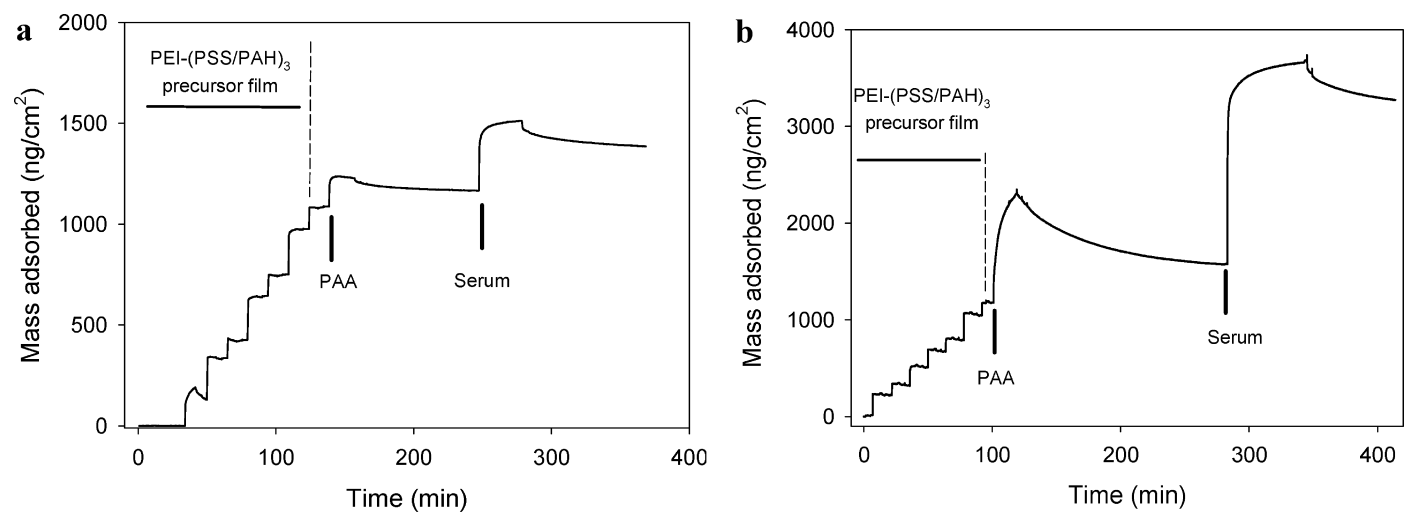

Figure 1. Evolution of the mass adsorbed, monitored (a) by OWLS and (b) by QCM as a function of time during the buildup of a PEI/(PSS/ $\mathrm{PAH})_{3} /$ PAA film, followed by contact with a serum solution at $4.4 \mathrm{mg} / \mathrm{mL}$.

error in $\mathrm{d} n / \mathrm{d} c$ due to the uncertainties in concentration and in the measured refractive indices was estimated to be on the order of 0.01 $\mathrm{cm}^{3} / \mathrm{g}$. The $\mathrm{d} n / \mathrm{d} c$ values of PAA-EO ${ }_{n}$-biotin with $n=0,3,9$, or 19 and $\mathrm{GR}=1,5,10$, or $25 \%$ are given in the SI.

The increment of mass adsorbed in biotinylated PAA $\left(\Delta q_{\mathrm{OWLS}}\right)$, as determined by OWLS, gives the possibility to estimate the number of biotin side groups per square nanometer for a known GR of the side groups on the polymer with the following equation

$$
n_{\text {biotin }}=\frac{\Delta q_{\text {OWLS }} \times N_{\mathrm{A}} \times \mathrm{GR}}{\text { mean molar mass in repeated unit of the polymer }}
$$

with $N_{\mathrm{A}}$ being Avogadro's constant. It is possible that not all of these groups are exposed on the surface.

For the calculation of the adsorbed mass of proteins, a refractive index increment of $0.18 \mathrm{~cm}^{3} / \mathrm{g}$ was used. ${ }^{49}$

QCM Measurements. Quartz crystal microbalance (QCM) measurements were performed on a QCM-D E4 device (Q-sense, Sweden) using gold-coated crystals at room temperature. The fundamental resonance frequency $\left(f_{1}\right)$ was on the order of $5 \mathrm{MHz}$. The changes in frequency $\left(\Delta f_{i}\right)$ at $15 \mathrm{MHz}(i=3)$, at $25 \mathrm{MHz}(i=5)$, and at $35 \mathrm{MHz}(i=7)$ were used for analysis. For a thin, rigid film (i.e., when $\Delta f_{\mathrm{i}} / i$ is independent of $i$ ), the mass, $q_{\mathrm{QCM}}\left(\mathrm{ng} / \mathrm{cm}^{2}\right)$, can be obtained by using the Sauerbrey equation ${ }^{50}$

$$
q_{\mathrm{QCM}}=-\frac{C \Delta f_{i}}{i}
$$

where $C$ is the mass sensitivity constant $\left(17.7 \mathrm{ng} \cdot \mathrm{cm}^{-2} \cdot \mathrm{Hz}^{-1}\right)$ of the QCM crystal, $i$ is the overtone number, and $\Delta f_{i} / i$ is expressed in Hertz. We verified that the normalized frequency changes, $\Delta f_{i} / i$, were equal to within $\pm 12 \%$ so that the use of the Sauerbrey equation to analyze our data was relevant. Because we assumed that the density of the film is close to $1 \mathrm{~g} \cdot \mathrm{cm}^{-3}$, we can evaluate the thickness of the polyelectrolyte layers, $d_{\mathrm{QCM}}(\mathrm{nm})$ :

$$
d_{\mathrm{QCM}}=-\frac{C \Delta f_{i}}{i} \times 0.01
$$

It must be noted that even if a slight error is made in the absolute value of the thickness it has no effect on the conclusions drawn from our studies because we mainly based our analysis on a comparison between the different systems.

Multilayer Assembly. The multilayers were assembled in situ in the measurement cell by bringing the substrate (QCM crystal or OWLS chip) into contact with the polyelectrolyte solutions by injecting $500 \mu \mathrm{L}$ into the measurement cell (internal volume of QCM cell $=40 \mu \mathrm{L}$ and internal volume of OWLS cell $=16 \mu \mathrm{L}$ ). The time of adsorption was $5 \mathrm{~min}$ in the case of PEI, PSS, and PAH and $12 \mathrm{~min}$ in the case of modified PAA. Each deposition was followed by rinsing with $2 \mathrm{~mL}$ of Tris- $\mathrm{NaCl}$ buffer solution for $5 \mathrm{~min}$. After the deposition of the last layer and rinsing, the multilayer was left to stabilize for 15 min in contact with the buffer solution prior to adsorption experiments with streptavidin or serum solutions.

Adsorption of Serum on PAA and Biotinylated PAATerminated Films. Serum adsorption was determined by QCM-D. A solution of FBS was obtained by the dilution of pure FBS with Tris$\mathrm{NaCl}$ buffer, followed by filtration, yielding a concentration of $10 \%$ by volume of FBS, corresponding to a total protein concentration of 4.4 $\mathrm{mg} / \mathrm{mL}$. The serum was put into contact with the architecture for 10 min, followed by a rinsing step with Tris- $\mathrm{NaCl}$ buffer for $10 \mathrm{~min}$. Adsorption was determined relative to the last deposited layer. Adsorption was measured after rinsing with buffer and the stabilization of the signal.

Adsorption of Streptavidin on PAA and Biotinylated PAATerminated Films. Streptavidin adsorption was tested by QCM-D. A solution of $0.2 \mathrm{mg} / \mathrm{mL}$ of streptavidin prepared in Tris- $\mathrm{NaCl}$ buffer was brought into contact with the different surfaces until the signal stabilized, followed by a rinsing step.

Bioaffinity Assay Protocol. For biosensing experiments after the buildup of the $\mathrm{PEI} /(\mathrm{PSS} / \mathrm{PAH})_{3}$ precursor multilayer and the adsorption of the $\mathrm{PAA}-\mathrm{EO}_{9}$-biotin $(25 \%)$ layer, the architecture was incubated with $1 \mathrm{~mL}$ of a $200 \mu \mathrm{g} / \mathrm{mL}$ streptavidin solution for $2 \mathrm{~h}$, followed by a rinsing step ( $5 \mathrm{~min}$ ) with $2 \mathrm{~mL}$ of Tris- $\mathrm{NaCl}$ buffer. Antibody adsorption was performed by injecting $1 \mathrm{~mL}$ of a $25 \mu \mathrm{g} / \mathrm{mL}$ biotinylated antiovalbumin solution for $2 \mathrm{~h}$, followed by a rinsing step with Tris- $\mathrm{NaCl}$ buffer at $400 \mu \mathrm{L} / \mathrm{min}$ for $5 \mathrm{~min}$. To test the biosensing architecture by OWLS, ovalbumin $(200 \mu \mathrm{g} / \mathrm{mL})$ and serum $(4.4 \mathrm{mg} /$ $\mathrm{mL}$ ) solutions were brought into contact with it by injecting the solutions at $100 \mu \mathrm{L} / \mathrm{min}$ until the stabilization of the signal. The protein injections were followed by a rinsing step with the buffer at $400 \mu \mathrm{L} / \mathrm{min}$ for OWLS experiments until the stabilization of the signal. For QCM experiments, the flow rate was fixed at $40 \mu \mathrm{L} / \mathrm{min}$ for ovalbumin injection and rinsing.

\section{RESULTS AND DISCUSSION}

Multilayered Films Terminated with a PAA Layer: Nonspecific and Specific Adsorption. To tailor the surface toward the specific adsorption of streptavidin and to evaluate its nonspecific interactions, we first adsorbed nonmodified PAA on the $\mathrm{PEI} /(\mathrm{PSS} / \mathrm{PAH})_{3}$ precursor film. The serum, which is a pool of proteins, is used as a model to evaluate the nonspecific interactions of the architecture. Two label-free techniques, OWLS and QCM, were used to characterize the protein adsorption. OWLS is an optical technique sensitive to the difference in the refractive indices of the adsorbed layer and the contacting solution. QCM, based on the piezoelectric properties of quartz, is sensitive to the deposited mass including bound water. These two techniques allow the determination of the adsorbed mass of polyelectrolyte or protein and the 
Table 1. Summary of the Data Obtained for the Adsorption of One Layer of PAA and PAA-EO ${ }_{n}-\mathrm{Biotin}$ on a PEI/(PSS/PAH $)_{3}$ Precursor Film ${ }^{a}$

\begin{tabular}{|c|c|c|c|c|c|c|}
\hline & \multirow[b]{2}{*}{ GR (\%) } & \multicolumn{2}{|c|}{$\begin{array}{l}\text { thickness of the polymer layer } \\
(\mathrm{nm})\end{array}$} & \multirow[b]{2}{*}{ thickness ratio $d_{\mathrm{QCM}} / d_{\mathrm{OWLS}}$} & \multirow[b]{2}{*}{ degree of hydration $H(\%)$} & \multirow[b]{2}{*}{ number of biotin per $\mathrm{nm}^{2}$} \\
\hline & & $d_{\mathrm{QCM}}$ & $d_{\text {OWLS }}$ & & & \\
\hline PAA & 0 & $7.7 \pm 0.7$ & $2.3 \pm 0.3$ & 3.3 & 83 & 0 \\
\hline \multirow[t]{3}{*}{ PAA-EO -biotin } & 1 & $10.8 \pm 0.6$ & $1.8 \pm 0.4$ & 6.0 & 81 & $0.13 \pm 0.01$ \\
\hline & 5 & $12.6 \pm 0.4$ & $1.9 \pm 0.2$ & 6.6 & 84 & $0.57 \pm 0.02$ \\
\hline & 10 & $12.4 \pm 0.5$ & $1.7 \pm 0.1$ & 7.3 & 83 & $1.12 \pm 0.08$ \\
\hline \multirow[t]{4}{*}{ PAA-EO ${ }_{3}$-biotin } & 1 & $8.6 \pm 0.9$ & $1.8 \pm 0.4$ & 4.8 & 77 & $0.12 \pm 0.01$ \\
\hline & 5 & $8.7 \pm 0.7$ & $1.9 \pm 0.3$ & 4.6 & 83 & $0.39 \pm 0.03$ \\
\hline & 10 & $14.4 \pm 0.4$ & $2.2 \pm 0.3$ & 6.5 & 80 & $1.35 \pm 0.07$ \\
\hline & 25 & $18.4 \pm 0.6$ & $2.6 \pm 0.6$ & 7.1 & 78 & $3.33 \pm 0.47$ \\
\hline \multirow[t]{4}{*}{ PAA-EO ${ }_{9}$-biotin } & 1 & $9.1 \pm 0.8$ & $1.4 \pm 0.1$ & 6.5 & 76 & $0.13 \pm 0.01$ \\
\hline & 5 & $13.3 \pm 1.2$ & $2.0 \pm 0.3$ & 6.7 & 87 & $0.41 \pm 0.01$ \\
\hline & 10 & $17.4 \pm 0.4$ & $2.5 \pm 0.6$ & 7.0 & 82 & $1.21 \pm 0.24$ \\
\hline & 25 & $31.7 \pm 1.3$ & $4.6 \pm 0.3$ & 6.9 & 73 & $3.26 \pm 0.37$ \\
\hline \multirow[t]{4}{*}{ PAA-EO ${ }_{19}$-biotin } & 1 & $9.7 \pm 0.2$ & $2.7 \pm 0.7$ & 3.6 & 83 & $0.10 \pm 0.01$ \\
\hline & 5 & $16.5 \pm 2.4$ & $2.4 \pm 0.7$ & 6.9 & 87 & $0.44 \pm 0.05$ \\
\hline & 10 & $18.8 \pm 3.6$ & $2.7 \pm 0.9$ & 7.0 & 92 & $0.49 \pm 0.04$ \\
\hline & 25 & $61.7 \pm 1.1$ & $8.8 \pm 1.8$ & 7.0 & 92 & $2.26 \pm 0.04$ \\
\hline
\end{tabular}

${ }^{a}$ Hydrated layer thicknesses, $d_{\mathrm{OCM}}$ 's, were obtained from QCM measurements by using eq 5 , and the dry layer thicknesses, $d_{\mathrm{OWLS}}$ 's, were measured by OWLS. The degree of hydration, $H$, was evaluated using eq 6. Surface densities in biotin moieties were determined by OWLS experiments using eq 3. Three experiments were performed to determine the mean value and the standard deviation in each case.

estimation of the degree of hydration of the adsorbed layer. The degree of hydration $(H \%)$ is given: ${ }^{11,51}$

$$
H=\frac{q_{\mathrm{QCM}}-q_{\mathrm{OWLS}}}{q_{\mathrm{QCM}}} \times 100
$$

When a serum solution at $4.4 \mathrm{mg} / \mathrm{mL}$ is brought into contact with a $\mathrm{PEI} /(\mathrm{PSS} / \mathrm{PAH})_{3}$ film terminated with a nonmodified PAA, adsorbed masses of proteins of about 217 and $1250 \mathrm{ng} /$ $\mathrm{cm}^{2}$ are measured by OWLS and QCM, respectively (Figure $1 \mathrm{a}, \mathrm{b})$. Almost a factor of 6 is observed between the two values because of the high water content of the adsorbed protein layer. Because QCM also measures the bound water of the layer, this technique may be several times more sensitive to protein interaction with a surface. The degree of hydration of the protein layer is evaluated to be $82 \%$. On the contrary to the proteins contained in serum, we observed that streptavidin does not adsorb on PAA at least in the QCM and OWLS sensitivity limits, which are both $1 \mathrm{ng} / \mathrm{cm}^{2}$. Having an acidic isoelectric point $(\mathrm{pI}=5)$, streptavidin has a net negative charge at $\mathrm{pH} 7.4$ leading to repulsive interactions with PAA that prevent its adsorption.

Preparation of the Library of Biotinylated PAA. To favor the specific adsorption of streptavidin, biotinylated PAA was synthesized with different grafting ratios (GR) and with different lengths of EO spacers to increase the accessibility to the grafted biotin moieties gradually and to prevent nonspecific

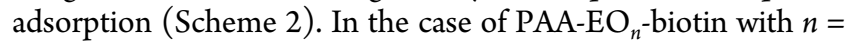
0 , the polyelectrolytes were prepared by a direct coupling reaction among the carboxylic groups of PAA, commercially available hydrazide-biotin, and $N$-(3-dimethylaminopropyl)- $N^{\prime}$ ethylcarbodiimide hydrochloride (EDCI). In the case of PAA$\mathrm{EO}_{n}$-biotin with $n=3,9$ or 19 , an aminated biotin was coupled to PAA by using carbodiimide or triazolol chemistry. Thus, a stable amide bond is formed, leading to a robust grafting of the biotin moieties along the PAA. First, biotin entities, $\mathrm{H}_{2} \mathrm{~N}-\mathrm{EO}_{n}$ biotin with different EO spacer lengths $(n=3$, 9, or 19) between the biotin and the free amino group, were synthesized.
After the monoprotection of the bis-amino ethylene oxide chains $\left(\mathrm{H}_{2} \mathrm{~N}-\mathrm{EO}_{n}-\mathrm{NH}_{2}, n=3,9\right.$, or 19) with butyloxycarbonyl groups (Boc), the coupling reaction with (D)-biotin provides the intermediate $\mathrm{BocHN}-\mathrm{EO}_{n}$-biotin. Deprotection in situ under acidic conditions allows us to get $\mathrm{H}_{2} \mathrm{~N}-\mathrm{EO}_{n}$-biotin $(n=$ 3 , 9, or 19) (characterization in SI).

In the presence of EDCI or triazolol reagent (HBTU), PAA and each $\mathrm{H}_{2} \mathrm{~N}-\mathrm{EO}_{n}$-biotin $(n=3,9$, or 19$)$ were dissolved together in an appropriate solvent in a proportion equivalent to the desired final GR. The dialysis of the grafted PAA yields 8393\%. The GR was determined by ${ }^{1} \mathrm{H}$ NMR or elemental analysis. These measured GRs for all samples and the different batches were found in the following intervals: 0.5-2, 3-6, 812 , and $23-27 \%$ for expected GRs of $1,5,10$, and $25 \%$, respectively. The experimental and expected GRs are thus in good agreement given the uncertainty of the determination techniques $( \pm 2 \%)$.

Characterization of the Biotinylated PAA Layer: Determination of the Biotin Surface Density. After its synthesis, PAA-EO-biotin was adsorbed on the PEI/(PSS/ $\mathrm{PAH})_{3}$ precursor film and characterized by OWLS and QCM. For each biotinylated PAA, three experiments were performed to determine the mean value and the standard deviation of the thicknesses (Table 1). Except in the case of PAA-EO-biotin,

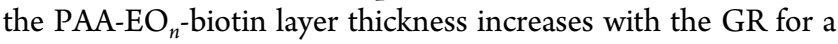
given length of EO. Furthermore, for a given GR, the thickness increases with the length of $\mathrm{EO}_{n}$. Thus, the accumulation of EO groups, through longer spacers or higher GR, increases the resulting thickness of the film probably because of the water bound to ethylene oxide groups. ${ }^{52}$ The ratio of the QCM and OWLS thicknesses $\left(d_{\mathrm{QCM}} / d_{\mathrm{OWLS}}\right)$ allows the estimation of the polymer layer hydration ${ }^{29,53}$ (Table 1). OWLS is mainly sensitive to the zone of the layer that possesses a high refractive index compared to that of water (i.e., rich in organic material) whereas QCM is more sensitive to the hydrated layer and thus to the hydrodynamic thickness. A high $d_{\mathrm{QCM}} / d_{\mathrm{OWLS}}$ ratio thus indicates a polymer layer that is less dense and more 
hydrated. ${ }^{53}$ For all studied $\mathrm{EO}_{n}$ lengths, the increase in biotin GR leads to a less dense and more diffuse biotinylated PAA layer. Strong hydration has been suggested to be a prerequisite to obtaining an antifouling coating. ${ }^{54}$ The degree of hydration of the nonmodified PAA is about $83 \%$. All PAA-EO -biotin $^{-}$ layers are hydrated to approximately $83 \pm 5 \%$. The degree of hydration seems to be nearly independent of the length of the EO arms and the grafting ratio, with only a slight increase for PAA-EO ${ }_{19}$-biotin layers.

The density of $\mathrm{EO}_{n}$-biotin moiteies present on the surface was determined by OWLS experiments using eq 1 (Figure 2).

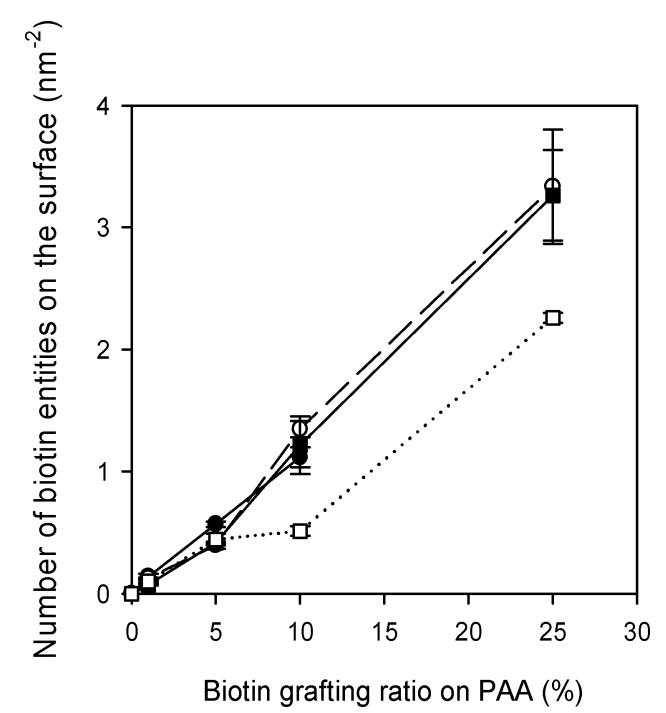

Figure 2. Number of biotin entities per square nanometer on the

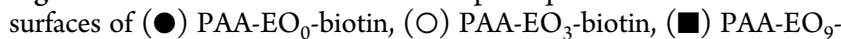

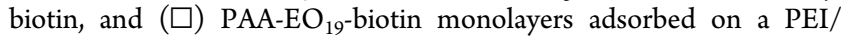
$(\mathrm{PSS} / \mathrm{PAH})_{3}$ precursor film as a function of the grafting ratio. All experiments have been repeated at least three times to obtain mean values and standard deviations.

The density of $\mathrm{EO}_{n}$-biotin groups increases steadily when the degree of functionalization increases from 1 to $25 \%$. Except for PAA-EO ${ }_{19}$-biotin, a master linear curve is obtained when the biotin surface density is plotted versus the grafting ratio (Figure 2). The amount of immobilized biotin adsorbed on the surface is independent of the length of the EO spacer. On the contrary, in the case of PAA-EO $\mathrm{EO}_{19}$-biotin, the $\mathrm{EO}_{n}$ arm seems to decrease the electrostatic adsorption of the modified polyanion and thus also the density of biotin moieties obtained. A maximum biotin

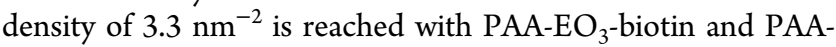
$\mathrm{EO}_{9}$-biotin, both at a GR of $25 \%$.

Multilayered Films Terminated by a Biotinylated PAA Layer: Nonspecific and Specific Adsorption. To evaluate the nonspecific (using a serum solution) and specific (using a

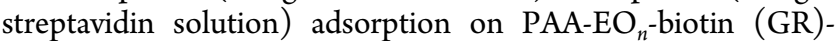
terminated $\mathrm{PEI} /(\mathrm{PSS} / \mathrm{PAH})_{3}$ films, the adsorbed mass of proteins was determined by QCM (Figure $3 \mathrm{a}, \mathrm{b}$ ). To get the mean value of the mass and its standard deviation, all of the experiments have been performed at least three times. Whatever the length of the $\mathrm{EO}_{n}$ spacer, the grafting of $1 \%$ in biotin leads to a strong decrease in serum adsorption compared to that of the nonmodified PAA $\left(1250 \mathrm{ng} / \mathrm{cm}^{2}\right.$, see Figure $1 \mathrm{~b}$ ), with the smallest adsorption obtained with the PAA-EO,-biotin layer $\left(480 \mathrm{ng} / \mathrm{cm}^{2}\right)$. PAA-EO ${ }_{0}$-biotin and $\mathrm{PAA}-\mathrm{EO}_{3}$-biotin layers did not allow for a decrease in the nonspecific adsorption of serum even for GR $=25 \%$. On the contrary, for PAA-EO ${ }^{-}$ biotin and PAA-EO $\mathrm{EO}_{19}$-biotin layers, the increase in GR from 1 to $25 \%$ induces a decrease and even the suppression of serum adsorption within the limits of sensitivity of QCM. Thus, a full antifouling film against serum is observed with $\mathrm{PAA}-\mathrm{EO}_{9}$-biotin (25\%)-terminated and PAA-EO ${ }_{19}$-biotin (25\%)-terminated $\mathrm{PEI} /(\mathrm{PSS} / \mathrm{PAH})_{3}$ films. This result is in striking contrast to that corresponding to $\mathrm{PAA}-\mathrm{EO}_{3}$-biotin $(25 \%)$. Thus, for the design of an antifouling surface, the length of the EO arms seems to be crucial compared to that of GR. A competition will occur between the antifouling effect of EO spacers and the availability of biotin moieties for streptavidin adsorption onto PAA-EO-biotin layers. It must be mentioned here that streptavidin is not adsorbed on a nonmodified PAA layer. In constrast, PAA-EO-biotin (1 and 5\%) layers allow the adsorption of roughly $2000 \mathrm{ng} / \mathrm{cm}^{2}$. When the length of the EO arms increases from 3 to 19 , the adsorption of streptavidin adsorption increases and reaches $2600 \mathrm{ng} / \mathrm{cm}^{2}$. This increase can be explained by the better accessibility of biotins born by longer spacers.

To discriminate the influence of the length of the EO arms and the surface density in biotin, we studied the correlation between the mass adsorption of proteins (serum and streptavidin) and the number of biotin moieties on the film
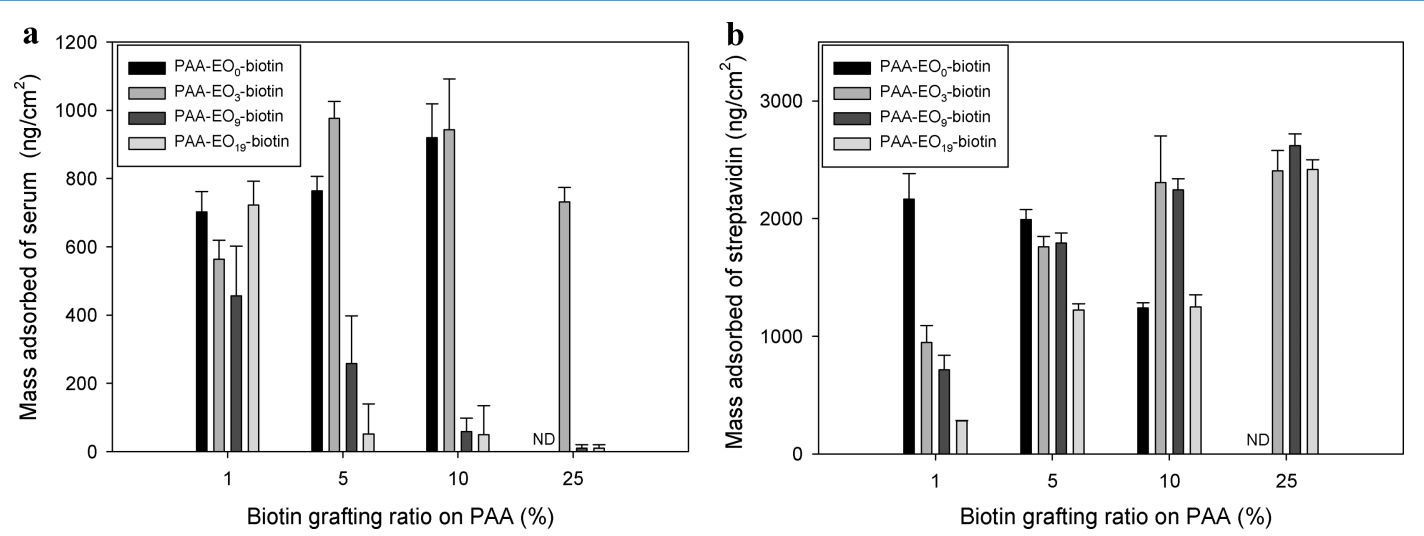

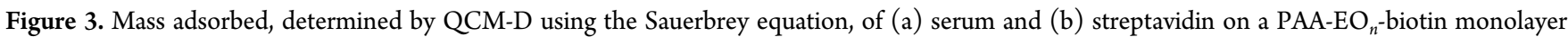
built on a precursor PEI/(PSS/PAH) $)_{3}$ film with $n=0,3$, 9, and 19 and with GR $=1,5,10$, and $25 \%$. The masses adsorbed were determined by QCM-D with $200 \mu \mathrm{g} / \mathrm{mL}$ streptavidin and $4.4 \mathrm{mg} / \mathrm{mL}$ serum solutions. All experiments have been repeated at least three times to get mean values and standard deviations of the mass adsorbed. ND stands for not determined. 


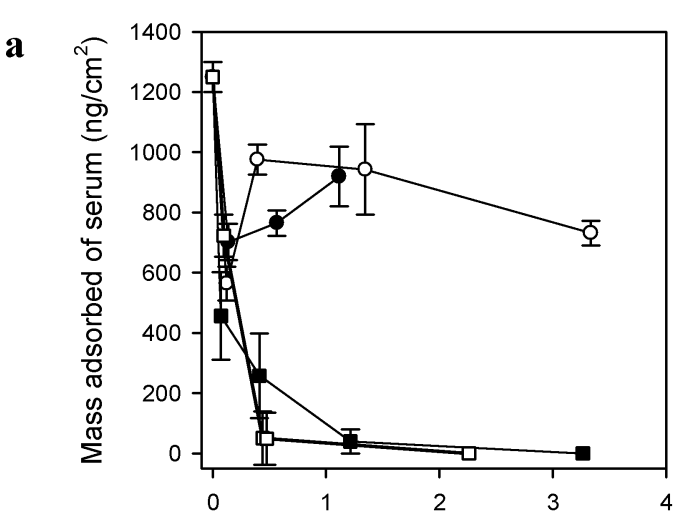

Number of biotin entities on the surface $\left(\mathrm{nm}^{-2}\right)$

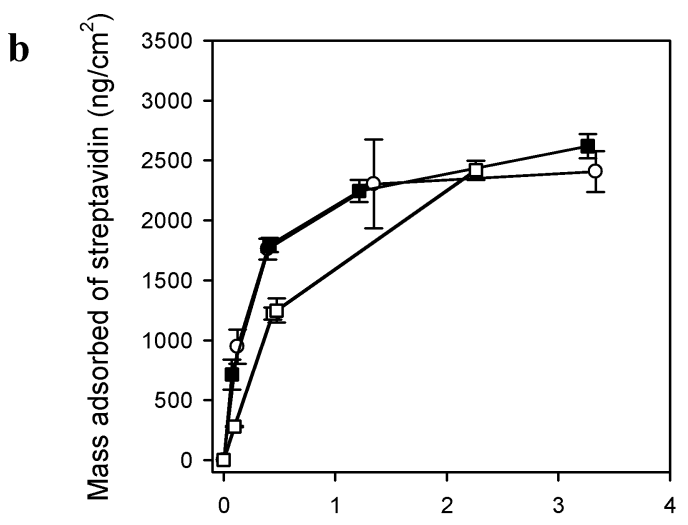

Number of biotin entities on the surface $\left(\mathrm{nm}^{-2}\right)$

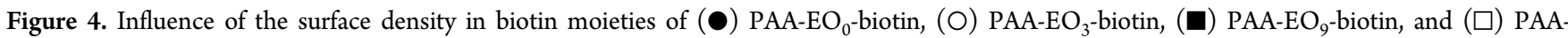
$\mathrm{EO}_{19}$-biotin monolayers adsorbed on a $\mathrm{PEI} /(\mathrm{PSS} / \mathrm{PAH})_{3}$ precursor film on the adsorption of (a) serum and (b) streptavidin. The adsorbed masses of proteins were determined by QCM-D. All experiments have been carried out at least three times to get the mean value and the standard deviation in each case.
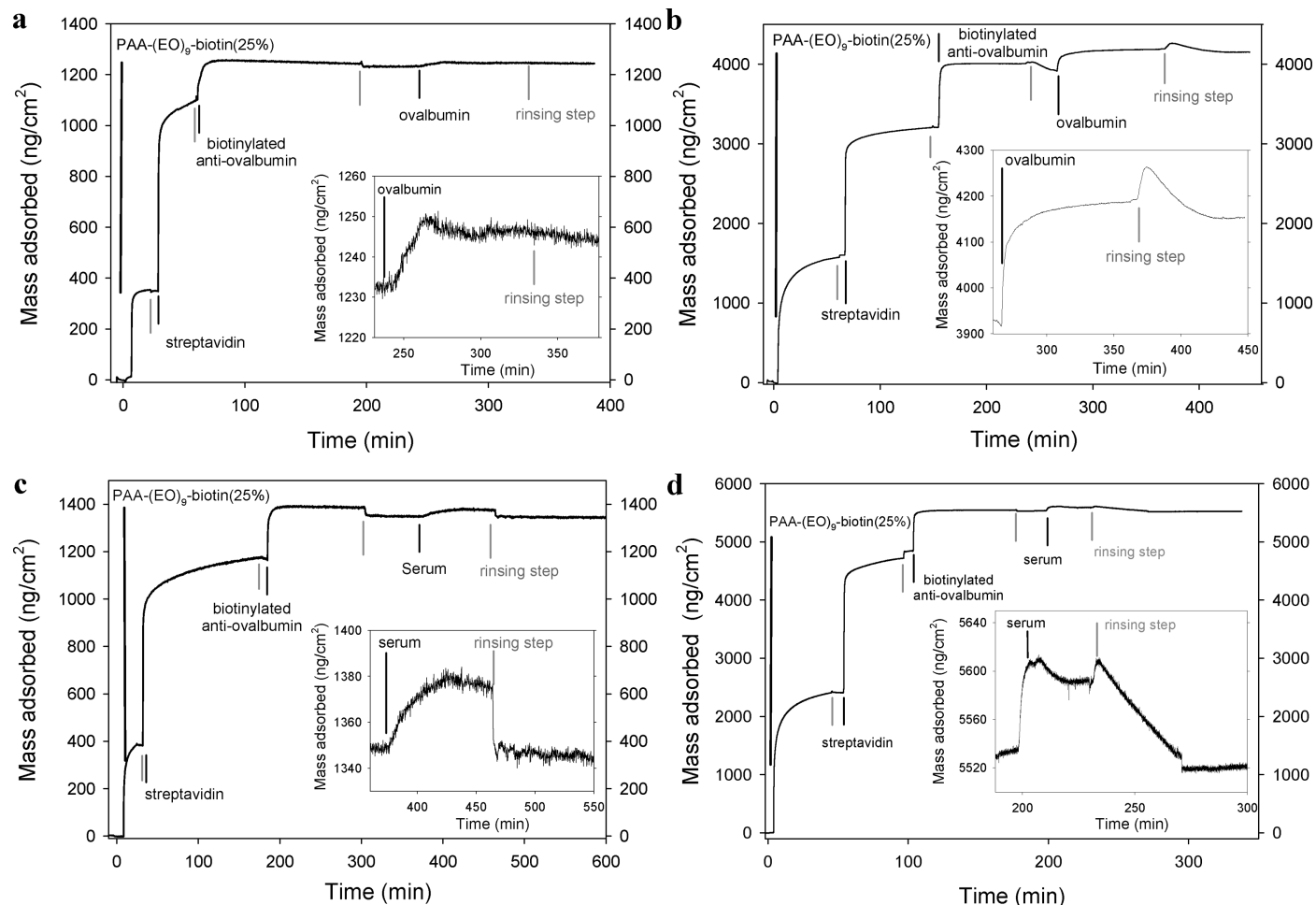

Figure 5. Evolution of the mass adsorbed, monitored by (a, c) OWLS and by (b, d) QCM, as a function of time during the sequential adsorption, on a $\mathrm{PEI} /(\mathrm{PSS} / \mathrm{PAH})_{3}$ precursor film, of $\mathrm{PAA}-\mathrm{EO}_{9}$-biotin $(25 \%)$, streptavidin, and biotinylated antiovalbumin, followed by contact with (a, b) ovalbumin and $(c, d)$ serum solutions. Each adsorption step was followed by a rinsing step. The mass adsorbed obtained by OWLS was plotted using eq 2 with $\mathrm{d} n / \mathrm{d} c=0.18 \mathrm{~cm}^{3} / \mathrm{g}$.

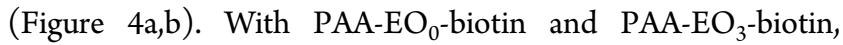
when the density of biotin moieties increases, serum adsorption reaches a plateau that represents $60 \%$ of the adsorption observed on nonmodified PAA (Figure 4a). On the contrary with $\mathrm{PAA}-\mathrm{EO}_{9}$-biotin and $\mathrm{PAA}-\mathrm{EO}_{19}$-biotin, the increase in biotin surface density leads to an elimination of the nonspecific adsorption of serum for at least 2.3 biotin moieties $/ \mathrm{nm}^{2}$. Thus, polyelectrolytes bearing EO chains with 9 or 19 units are as efficient as longer PEO chains with 44 units (MW 2000) at suppressing the nonspecific adsorption of protein. ${ }^{8,24}$ This result is comparable to the antifouling properties of EO SAMs, giving well-ordered chains on the surface, obtained for thiol-EO derivatives of 7 and 9 units. ${ }^{10,55}$ In the case of grafted EO chains, an antifouling surface is obtained using alkyl chains (911 carbons) terminated by 3-9 EO units with a high surface density (>10 EO units $\left./ \mathrm{nm}^{2}\right) .{ }^{56-58}$ In the case of a nonalkylated $\mathrm{EO}_{n}$ monolayer, 16 units were required to be repellent against bovine serum albumin. 59

When the adsorbed mass of streptavidin is plotted as a function of the surface density of biotin, a common curve is obtained for PAA-EO ${ }^{-}$-biotin with $n=0,3$, and 9 (Figure 4b). This means that for the same density in biotin almost the same mass of streptavidin can be immobilized on the surface of PAA$\mathrm{EO}_{n}$-biotin layers independently of $n$, except for $n=19$. When 
the biotin surface density is increased, the mass of streptavidin adsorbed increases up to a plateau reached for 1.2 biotin moieties $/ \mathrm{nm}^{2}$. Streptavidin adsorption is maximal for 3.3 moieties $/ \mathrm{nm}^{2}$ for the $\mathrm{PAA}-\mathrm{EO}_{9}$-biotin (25\%) layer. For the same surface density in biotin, the amount of adsorbed streptavidin is systematically lower for the PAA-EO -biotin $_{19}$ layer than for the other biotinylated PAA. This difference is visible for densities of less than 2 moieties $/ \mathrm{nm}^{2}$. This indicates that a non-negligeable part of biotin is inaccessible to streptavidin. This could be explained by the conformation of $\mathrm{EO}_{19}$ arms hiding the biotin moieties.

Biosensor Architectures Based on the StreptavidinBiotin System: Specific Adsorption and Antifouling Effect. Taking into account that films displaying no adsorption of serum and a strong adsorption of streptavidin are ideal candidates for biosensing applications, a suitable platform for the immobilization of a biotinylated antibody is obtained using a monolayer of $\mathrm{PAA}-\mathrm{EO}_{9}$-biotin deposited on a $\mathrm{PEI} /$ (PSS/ $\mathrm{PAH})_{3}$ precursor film (Scheme $1 \mathrm{~b}$ ). We choose as an immunoassay model the antiovalbumin/ovalbumin complex. The thickness of the platform, $\mathrm{PEI} /(\mathrm{PSS} / \mathrm{PAH})_{3} / \mathrm{PAA}-\mathrm{EO}_{9}$ biotin/streptavidin/biotinylated antiovalbumin, is $27 \mathrm{~nm}$ (Figure S-1 in SI). The platform thickness is far below the penetration depth of the laser light $(\lambda=632.8 \mathrm{~nm})$ evaluated to 200-300 nm. Thanks to the homogeneous and isotropic monolayer model that we developed to treat the data, ${ }^{47}$ OWLS experiments allow the monitoring of the mass of ovalbumin adsorbed on such a platform. A typical mass adsorption curve, derived from an in situ OWLS measurement, was obtained during the sequential adsorption of $\mathrm{PAA}-\mathrm{EO}_{9}$-biotin, streptavidin, biotinylated antiovalbumin, and ovalbumin (Figure 5a). Two hours of contact with a $200 \mu \mathrm{g} / \mathrm{mL}$ solution of streptavidin is needed to stabilize the signal, with a small decrease after the rinsing step. Streptavidin, with a concentration of $706 \pm 42 \mathrm{ng} / \mathrm{cm}^{2}$ corresponding to $11.76 \pm 0.70$ $\mathrm{pmol} / \mathrm{cm}^{2}$, is bound to $\mathrm{PAA}-\mathrm{EO}_{9}$-biotin-terminated architectures. It follows from its $2 \mathrm{D}$ structure $\left(5.5 \times 4.5 \mathrm{~nm}^{2}\right)^{60}$ that a closely packed streptavidin monolayer corresponds to about 6.7 $\mathrm{pmol} / \mathrm{cm}^{2} .{ }^{8}$ Thus, a dense layer of protein is adsorbed on PAA$\mathrm{EO}_{9}$-biotin. This could be explained by the possible tilt of streptavidin with respect to the surface, which may be permitted by the flexibility of the biotinylated $\mathrm{EO}_{9}$ arm. Following the adsorption of streptavidin, biotinylated antiovalbumin molecules were rapidly bound to the surface through the remaining biotin binding sites of streptavidin. Almost no antibody was removed by the rinsing step. Thus, $111 \pm 26 \mathrm{ng} /$ $\mathrm{cm}^{2}$ (representing $0.74 \pm 0.18 \mathrm{pmol} / \mathrm{cm}^{2}$ ) of biotinylated antiovalbumin can be immobilized on the PAA-EO $\mathrm{EO}_{9}$-biotin/ streptavidin platform. The molecular dimensions of nonmodified immunoglobulin antibodies being $14.3 \times 5.9 \mathrm{~nm}^{2}$ the adsorbed mass of a closely packed monolayer of biotinylated antiovalbumin corresponds to about $1.97 \mathrm{pmol} /$ $\mathrm{cm}^{2}$. Therefore, the surface density of antiovalbumin obtained in the present system is about $40 \%$. This partial coverage of the surface by biotinylated antiovalbumin could be due to the fact that some of biotin binding sites of streptavidin are not accessible and are sterically blocked by adjacent streptavidin molecules.

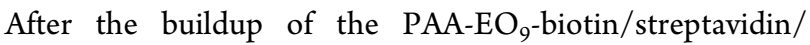
biotinylated antiovalbumin platform, the injection of $200 \mu \mathrm{g} /$ $\mathrm{L}$ of ovalbumin solution induced a protein adsorption of $16 \pm 3$ $\mathrm{ng} / \mathrm{cm}^{2}$ (representing $0.35 \pm 0.08 \mathrm{pmol} / \mathrm{cm}^{2}$ ) after the rinsing step (Figure 5a, inset). It takes about $2 \mathrm{~h}$ for the ovalbumin signal to stabilize. The ratio of antiovalbumin to ovalbumin is equal to 2. This suggests that two antiovalbumin molecules capture one ovalbumin molecule.

The versatility of PEM films allows the building of the PAA$\mathrm{EO}_{9}$-biotin/strepavidin/biotinylated antiovalbumin platform for performing QCM experiments (Figure 5b). Table 2 summa-

Table 2. Mass Adsorbed, Determined by QCM and by

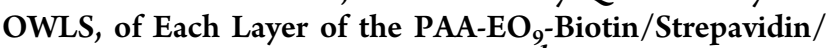
Biotinylated Antiovalbumin Platform ${ }^{a, b}$

\begin{tabular}{|c|c|c|c|}
\hline \multirow[b]{2}{*}{ layers } & \multicolumn{2}{|c|}{ mass adsorbed $\left(\mathrm{ng} / \mathrm{cm}^{2}\right)$} & \multirow{2}{*}{$\begin{array}{c}\text { degree of hydration } H \\
(\%)\end{array}$} \\
\hline & qowLS & $q_{\mathrm{QCM}}$ & \\
\hline PAA-EO ${ }_{9}$-biotin & $538 \pm 61$ & $1990 \pm 200$ & 73 \\
\hline streptavidin & $706 \pm 42$ & $2100 \pm 150$ & 66 \\
\hline $\begin{array}{l}\text { biotinylated } \\
\text { antiovalbumin }\end{array}$ & $111 \pm 26$ & $696 \pm 22$ & 84 \\
\hline ovalbumin & $16 \pm 3$ & $199 \pm 20$ & 92 \\
\hline
\end{tabular}

${ }^{a}$ Three experiments were performed to get the mean values and the standard deviations. ${ }^{b}$ The hydrated mass adsorbed, $q_{\mathrm{QCM}}$, was obtained from QCM measurements by using eq 4, and the dry mass adsorbed, $q_{\text {OWLS }}$, was measured by OWLS using eq 2 using the appropriate $\mathrm{d} n / \mathrm{dc}$. The degree of hydration, $H$, was evaluated using eq 6. Three experiments were performed to determine the mean values and the standard deviation of the different data.

rizes the adsorbed mass of each layer, determined by QCM and OWLS. The degrees of hydration of biotinylated PAA, streptavidin, and the biotinylated antibody are similar (70$80 \%)$. When ovalbumin is placed in contact with the platform, a mass adsorption of $199 \pm 20 \mathrm{ng} / \mathrm{cm}^{2}$ is obtained (Figure $5 \mathrm{~b}$, inset). The degree of hydration of the ovalbumin layer, evaluated at $92 \%$, allows for higher sensitivity in terms of the quantification of the mass adsorbed by QCM.

Because serum, which contains mainly albumin, is commonly examined in clinical diagnosis, it is useful in testing the resistance of the proposed biosensing platform to nonspecific adsorption. We first performed different experiments using fetal bovine serum on the $\mathrm{PAA}-\mathrm{EO}_{9}$-biotin-terminated $\mathrm{PSS} / \mathrm{PAH}$ precursor film. A serum solution followed by a streptavidin solution, a streptavidin solution followed by a serum solution, and a solution of streptavidin prepared in diluted serum (200 $\mu \mathrm{g} / \mathrm{mL}$ for $4.4 \mathrm{mg} / \mathrm{mL}$, respectively) were brought into contact with the architecture. Whatever the order when serum and streptavidin solutions were sequentially brought into contact with the architecture, no adsorption of serum was observed. This strengthens the antifouling character of $\mathrm{PAA}-\mathrm{EO}_{9}$-biotin layers. When the streptavidin solution was brought into contact with the architecture after the serum solution or in the presence of serum, the mass of streptavidin adsorbed was smaller by about $15 \%$ compared to that obtained without serum. Finally, a serum solution was brought into contact with the PAA-EO ${ }_{9}$ biotin/strepavidin/biotinylated antiovalbumin biosensing platform and monitored by OWLS and QCM. A small amount of serum adsorption was observed that was completely removed by the rinsing step (Figure $5 c, d$, insets). In summary, in all cases tested, no serum adsorption was detected (i.e., the mass of serum was less than the sensitivity of both the OWLS and the QCM techniques $\left.\left(\sim 1 \mathrm{ng} / \mathrm{cm}^{2}\right)\right)$. This shows that the present biosensing platform is highly selective and promising for biomedical applications. 


\section{CONCLUSIONS}

PAA- $-\mathrm{EO}_{9}$-biotin is shown to be a promising polymer for the functionalization of bioaffinity sensors through the use of PEM precursor films that can be adsorbed on all kinds of surfaces. The nonspecific adsorption of serum was found to be below the detection limit of OWLS and QCM $\left(\sim 1 \mathrm{ng} / \mathrm{cm}^{2}\right)$. The library of synthesized PAA-EO ${ }_{n}$-biotin (GR) allows for the tuning of the surface density in $\mathrm{EO}_{n}$-biotin. On the contrary to published approaches, no additional EO chains have been used to ensure the antifouling property of the surface. In our case, this role belongs to the $\mathrm{EO}_{9}$ spacer in addition to the accessibility of the biotin group. Because of this dual role, the specific adsorption of streptavidin was favored by simultaneously limiting the nonspecific adsorption of serum. Finally, an optimized platform based on the PAA-EO -biotin (25\%)/streptavidin/biotinylatedantiovalbumin antibody architecture was built. This platform demonstrated promising performance as an interface architecture for bioaffinity sensing with the specific binding of ovalbumin and no adsorption of serum showing its high selectivity.

\section{ASSOCIATED CONTENT}

\section{(S Supporting Information}

Complementary experimental section: preparation of PAA$\mathrm{EO}_{n}$-biotin polymers and evolution of the film thickness during the buildup of $\mathrm{PEI} /(\mathrm{PSS} / \mathrm{PAH})_{3}$-PAA-EO -biotin (25\%)streptavidin-biotinylated antiovalbumin, followed by contact with ovalbumin. This material is available free of charge via the Internet at http://pubs.acs.org.

\section{AUTHOR INFORMATION}

\section{Corresponding Author}

*Phone: +33 (0)3 884141 60. Fax: +33 (0)3 884140 99. Email: fouzia.boulmedais@ics-cnrs.unistra.fr.

\section{Notes}

The authors declare no competing financial interest.

\section{ACKNOWLEDGMENTS}

J.D., A.G., and T.G. were supported by a doctoral fellowship from the Venezuelian Government (FONACIT), by ANR Biostretch (ANR-10-BLAN-0818), and by the International Center for Frontier Research in Chemistry (LabEX project, icFRC, Strasbourg), respectively. Financial contributions from ANR Biostretch (ANR-10-BLAN-0818) and Institut Universitaire de France are gratefully acknowledged. Elö̈se Gaillard, Laura Kelhetter, Laëtitia Dupouy, and Eric Gonthier are gratefully acknowledged for their technical assistance.

\section{REFERENCES}

(1) Hanash, S. M.; Pitteri, S. J.; Faca, V. M. Mining the plasma proteome for cancer biomarkers. Nature 2008, 452, 571-579.

(2) Sawyers, C. L. The cancer biomarker problem. Nature 2008, 452, 548-552.

(3) Radpour, R.; Barekati, Z.; Kohler, C.; Holzgreve, W.; Zhong, X. Y. New trends in molecular biomarker discovery for breast cancer. Genet. Test. Mol. Biomarkers 2009, 13, 565-571.

(4) Paulovich, A. G.; Whiteaker, J. R.; Hoofnagle, A. N.; Wang, P. The interface between biomarker discovery and clinical validation: the tar pit of the protein biomarker pipeline. Proteomics: Clin. Appl. 2008, 2, 1386-1402

(5) Cooper, M. A. Label-free screening of bio-molecular interactions. Ana.l Bioanal. Chem. 2003, 377, 834-842.
(6) Hoa, X. D.; Kirk, A. G.; Tabrizian, M. Towards integrated and sensitive surface plasmon resonance biosensors: a review of recent progress. Biosens. Bioelectron. 2007, 23, 151-160.

(7) Zhu, Z. R.; Cuozzo, J. High-throughput affinity-based technologies for small-molecule drug discovery. J. Biomol. Screening 2009, 14, 1157-1164.

(8) Huang, N.-P.; Vörös, J.; De Paul, S. M.; Textor, M.; Spencer, N. D. Biotin-derivatized poly(L-lysine)-g-poly(ethylene glycol): a novel polymeric interface for bioaffinity sensing. Langmuir 2002, 18, 220230.

(9) Nileback, E.; Westberg, F.; Deinum, J.; Svedhem, S. Viscoelastic sensing of conformational changes in plasminogen induced upon binding of low molecular weight compounds. Anal. Chem. 2010, 82, 8374-8376.

(10) Nileback, E.; Feuz, L.; Uddenberg, H.; Valiokas, R.; Svedhem, S. Characterization and application of a surface modification designed for QCM-D studies of biotinylated biomolecules. Biosens. Bioelectron. 2011, 28, 407-413.

(11) Edvardsson, M.; Svedhem, S.; Wang, G.; Richter, R.; Rodahl, M.; Kasemo, B. QCM-D and reflectometry instrument: applications to supported lipid structures and their biomolecular interactions. Anal. Chem. 2009, 81, 349-361.

(12) Chapman, R. G.; Ostuni, E.; Takayama, S.; Holmlin, R. E.; Yan, L.; Whitesides, G. M. Surveying for surfaces that resist the adsorption of proteins. J. Am. Chem. Soc. 2000, 122, 8303-8304.

(13) Luk, Y. Y.; Kato, M.; Mrksich, M. Self-assembled monolayers of alkanethiolates presenting mannitol groups are inert to protein adsorption and cell attachment. Langmuir 2000, 16, 9604-9608.

(14) Zwaal, R. F. A.; Comfurius, P.; Vandeenen, L. L. M. Membrane asymmetry and blood-coagulation. Nature 1977, 268, 358-360.

(15) Zhang, Z.; Chao, T.; Chen, S. F.; Jiang, S. Y. Superlow fouling sulfobetaine and carboxybetaine polymers on glass slides. Langmuir 2006, 22, 10072-10077.

(16) Prime, K. L.; Whitesides, G. M. Self-assembled organic monolayers - model systems for studying adsorption of proteins at surfaces. Science 1991, 252, 1164-1167.

(17) Herrwerth, S.; Eck, W.; Reinhardt, S.; Grunze, M. Factors that determine the protein resistance of oligoether self-assembled monolayers - internal hydrophilicity, terminal hydrophilicity, and lateral packing density. J. Am. Chem. Soc. 2003, 125, 9359-9366.

(18) Park, K. D.; Kim, Y. S.; Han, D. K.; Kim, Y. H.; Lee, E. H.; Suh, H.; Choi, K. S. Bacterial adhesion on PEG modified polyurethane surfaces. Biomaterials 1998, 19, 851-9.

(19) Moro, T.; Takatori, Y.; Ishihara, K.; Konno, T.; Takigawa, Y.; Matsushita, T.; Chung, U. I.; Nakamura, K.; Kawaguchi, H. Surface grafting of artificial joints with a biocompatible polymer for preventing periprosthetic osteolysis. Nat. Mater. 2004, 3, 829-836.

(20) Miyazawa, K.; Winnik, F. M. Synthesis of phosphorylcholinebased hydrophobically modified polybetaines. Macromolecules 2002, $35,2440-2444$.

(21) Reisch, A.; Voegel, J.-C.; Decher, G.; Schaaf, P.; Mésini, P. J. Synthesis of polyelectrolytes bearing phosphorylcholine moieties. Macromol. Rapid Commun. 2007, 28, 2217-2223.

(22) Huang, N.-P.; Michel, R.; Vörös, J.; Textor, M.; Hofer, R.; Rossi, A.; Elbert, D. L.; Hubbell, J. A.; Spencer, N. D. Poly(L-lysine)-gpoly(ethylene glycol) layers on metal oxide surfaces: surface-analytical characterization and resistance to serum and fibrinogen adsorption. Langmuir 2001, 17, 489-498.

(23) Kenausis, G. L.; Vörös, J.; Elbert, D. L.; Huang, N.; Hofer, R.; Ruiz-Taylor, L.; Textor, M.; Hubbell, J. A.; Spencer, N. D. Poly(Llysine)-g-poly(ethylene glycol) layers on metal oxide surfaces: attachment mechanism and effects of polymer architecture on resistance to protein adsorption. J. Phys. Chem. B 2000, 104, 32983309.

(24) Boulmedais, F.; Frisch, B.; Etienne, O.; Lavalle, P.; Picart, C.; Ogier, J.; Voegel, J.-C.; Schaaf, P.; Egles, C. Polyelectrolyte multilayer films with pegylated polypeptides as a new type of anti-microbial protection for biomaterials. Biomaterials 2004, 25, 2003-2011. 
(25) Feng, W.; Zhu, S. P.; Ishihara, K.; Brash, J. L. Adsorption of fibrinogen and lysozyme on silicon grafted with poly(2-methacryloyloxyethyl phosphorylcholine) via surface-initiated atom transfer radical polymerization. Langmuir 2005, 21, 5980-5987.

(26) Salloum, D. S.; Olenych, S. G.; Keller, T. C. S.; Schlenoff, J. B. Vascular smooth muscle cells on polyelectrolyte multilayers: hydrophobicity-directed adhesion and growth. Biomacromolecules 2005, 6, 161-167.

(27) Reisch, A.; Hemmerlé, J.; Voegel, J.-C.; Gonthier, E.; Decher, G.; Benkirane-Jessel, N.; Chassepot, A.; Mertz, D.; Lavalle, P.; Mésini, P.; Schaaf, P. Polyelectrolyte multilayer coatings that resist protein adsorption at rest and under stretching. J. Mater. Chem. 2008, 18, $4242-4245$.

(28) Reisch, A.; Hemmerlé, J.; Chassepot, A.; Lefort, M.; BenkiraneJessel, N.; Candolfi, E.; Mésini, P.; Letscher-Bru, V.; Voegel, J.-C.; Schaaf, P. Anti-fouling phosphorylcholine bearing polyelectrolyte multilayers: cell adhesion resistance at rest and under stretching. Soft Matter 2010, 6, 1503-1512.

(29) Reisch, A.; Voegel, J.-C.; Gonthier, E.; Decher, G.; Senger, B.; Schaaf, P.; Mésini, P. J. Polyelectrolyte multilayers capped with polyelectrolytes bearing phosphorylcholine and triethylene glycol groups: parameters influencing antifouling properties. Langmuir 2009, 25, 3610-3617.

(30) Decher, G. Fuzzy nanoassemblies: toward layered polymeric multicomposites. Science 1997, 277, 1232-1237.

(31) Brusatori, M. A.; Van Tassel, P. R. Biosensing under an applied voltage using optical waveguide lightmode spectroscopy. Biosens. Bioelectron. 2003, 18, 1269-1277.

(32) Caruso, F.; Niikura, K.; Furlong, D. N.; Okahata, Y. 2. Assembly of alternating polyelectrolyte and protein multilayer films for immunosensing. Langmuir 1997, 13, 3427-3433.

(33) Hillberg, A. L.; Tabrizian, M. Biorecognition through layer-bylayer polyelectrolyte assembly: in-situ hybridization on living cells. Biomacromolecules 2006, 7, 2742-2750.

(34) Jewell, C. M.; Fuchs, S. M.; Flessner, R. M.; Raines, R. T.; Lynn, D. M. Multilayered films fabricated from an oligoarginine-conjugated protein promote efficient surface-mediated protein transduction. Biomacromolecules 2007, 8, 857-863.

(35) Zelikin, A. N.; Quinn, J. F.; Caruso, F. Disulfide cross-linked polymer capsules: en route to biodeconstructible systems. Biomacromolecules 2006, 7, 27-30.

(36) Thierry, B.; Winnik, F. M.; Merhi, Y.; Silver, J.; Tabrizian, M. Bioactive coatings of endovascular stents based on polyelectrolyte multilayers. Biomacromolecules 2003, 4, 1564-1571.

(37) Vautier, D.; Karsten, V.; Egles, C.; Chluba, J.; Schaaf, P.; Voegel, J.-C.; Ogier, J. Polyelectrolyte multilayer films modulate cytoskeletal organization in chondrosarcoma cells. J. Biomater. Sci., Polym. Ed. 2002, $13,713-732$.

(38) Jessel, N.; Atalar, F.; Lavalle, P.; Mutterer, J.; Decher, G.; Schaaf, P.; Voegel, J.-C.; Ogier, J. Bioactive coatings based on a polyelectrolyte multilayer architecture functionalized by embedded proteins. Adv. Mater. 2003, 15, 692-695.

(39) Lvov, Y.; Ariga, K.; Ichinose, I.; Kunitake, T. Molecular film assembly via layer-by-layer adsorption of oppositely charged macromolecules (linear polymer, protein and clay) and concanavalin A and glycogen. Thin Solid Films 1996, 285, 797-801.

(40) Chluba, J.; Voegel, J.-C.; Decher, G.; Erbacher, P.; Schaaf, P.; Ogier, J. Peptide hormone covalently bound to polyelectrolytes and embedded into multilayer architectures conserving full biological activity. Biomacromolecules 2001, 2, 800-805.

(41) Jessel, N.; Oulad-Abdeighani, M.; Meyer, F.; Lavalle, P.; Haikel, Y.; Schaaf, P.; Voegel, J.-C. Multiple and time-scheduled in situ DNA delivery mediated by $\beta$-cyclodextrin embedded in a polyelectrolyte multilayer. Proc. Natl. Acad. Sci. U.S.A. 2006, 103, 8618-8621.

(42) Benkirane-Jessel, N.; Schwinté, P.; Falvey, P.; Darcy, R.; Haikel, Y.; Schaaf, P.; Voegel, J.-C.; Ogier, J. Build-up of polypeptide multilayer coatings with anti-inflammatory properties based on the embedding of piroxicam-cyclodextrin complexes. Adv. Funct. Mater. 2004, 14, 174-182.
(43) Schwinté, P.; Voegel, J.-C.; Picart, C.; Haikel, Y.; Schaaf, P.; Szalontai, B. Stabilizing effects of various polyelectrolyte multilayer films on the structure of adsorbed/embedded fibrinogen molecules: an ATR-FTIR study. J. Phys. Chem. B 2001, 105, 11906-11916.

(44) Wilchek, M.; Bayer, E. A. Foreword and introduction to the book (strept)avidin-biotin system. Biomol Eng. 1999, 16, 1-4.

(45) Vörös, J.; Ramsden, J. J.; Csucs, G.; Szendro, I.; De Paul, S. M.; Textor, M.; Spencer, N. D. Optical grating coupler biosensors. Biomaterials 2002, 23, 3699-3710.

(46) Picart, C.; Ladam, G.; Senger, B.; Voegel, J.-C.; Schaaf, P.; Cuisinier, F. J. G.; Gergely, C. Determination of structural parameters characterizing thin films by optical methods: a comparison between scanning angle reflectometry and optical waveguide lightmode spectroscopy. J. Chem. Phys. 2001, 115, 1086-1094.

(47) Picart, C.; Gergely, C.; Arntz, Y.; Voegel, J.-C.; Schaaf, P.; Cuisinier, F. J. G.; Senger, B. Measurement of film thickness up to several hundreds of nanometers using optical waveguide lightmode spectroscopy. Biosens. Bioelectron. 2004, 20, 553-561.

(48) Höök, F.; Vörös, J.; Rodahl, M.; Kurrat, R.; Boni, P.; Ramsden, J. J.; Textor, M.; Spencer, N. D.; Tengvall, P.; Gold, J.; Kasemo, B. A comparative study of protein adsorption on titanium oxide surfaces using in situ ellipsometry, optical waveguide lightmode spectroscopy, and quartz crystal microbalance/dissipation. Colloids Surf., B 2002, 24, 155-170.

(49) Ball, V.; Ramsden, J. J. Absence of surface exclusion in the first stage of lysozyme adsorption is driven through electrostatic selfassembly. J. Phys. Chem. B 1997, 101, 5465-5469.

(50) Sauerbrey, G. Verwendung von Schwingquartzen zur Wägung dünner Schichten und zur Mikrowägung. Z. Phys. 1959, 155, 206-222.

(51) Konradin, R.; Textor, M.; Reimhult, E. Using complementary acoustic and optical techniques for quantitative monitoring of biomolecular adsorption at interfaces. Biosensors 2012, 2, 341-376.

(52) Harder, P.; Grunze, M.; Dahint, R.; Whitesides, G. M.; Laibinis, P. E. Molecular conformation in oligo(ethylene glycol)-terminated self-assembled monolayers on gold and silver surfaces determines their ability to resist protein adsorption. J. Phys. Chem. B 1998, 102, 426436.

(53) Abdelkebir, K.; Gaudiere, F.; Morin-Grognet, S.; Coquerel, G.; Labat, B.; Atmani, H.; Ladam, G. Evidence of different growth regimes coexisting within biomimetic layer-by-layer films. Soft Matter 2011, 7, 9197-9205.

(54) Chapman, R. G.; Ostuni, E.; Liang, M. N.; Meluleni, G.; Kim, E.; Yan, L.; Pier, G.; Warren, H. S.; Whitesides, G. M. Polymeric thin films that resist the adsorption of proteins and the adhesion of bacteria. Langmuir 2001, 17, 1225-1233.

(55) Prime, K. L.; Whitesides, G. M. Adsorption of proteins onto surfaces containing end-attached oligo(ethylene oxide) - a model system using self-assembled monolayers. J. Am. Chem. Soc. 1993, 115, 10714-10721.

(56) Li, Y.; Wang, J.; Cai, C. Z. Rapid grafting of azido-labeled oligo(ethylene glycol)s onto an alkynyl-terminated mono layer on nonoxidized silicon via microwave-assisted "click" reaction. Langmuir 2011, 27, 2437-2445.

(57) Bocking, T.; Kilian, K. A.; Hanley, T.; Ilyas, S.; Gaus, K.; Gal, M.; Gooding, J. J. Formation of tetra(ethylene oxide) terminated Si-C linked monolayers and their derivatization with glycine: An example of a generic strategy for the immobilization of biomolecules on silicon. Langmuir 2005, 21, 10522-10529.

(58) Rosso, M.; Nguyen, A. T.; de Jong, E.; Baggerman, J.; Paulusse, J. M. J.; Giesbers, M.; Fokkink, R. G.; Norde, W.; Schroen, K.; van Rijn, C. J. M.; Zuilhof, H. Protein-repellent silicon nitride surfaces: UV-induced formation of oligoethylene oxide monolayers. ACS Appl. Mater. Interfaces 2011, 3, 697-704.

(59) Perez, E.; Lahlil, K.; Rougeau, C.; Moraillon, A.; Chazalviel, J.N.; Ozanam, F.; Gouget-Laemmel, A.-C. Influence of the molecular design on the antifouling performance of poly(ethylene glycol) monolayers grafted on (111) Si. Langmuir 2012, 28, 14654-14664.

(60) Darst, S. A.; Ahlers, M.; Meller, P. H.; Kubalek, E. W.; Blankenburg, R.; Ribi, H. O.; Ringsdorf, H.; Kornberg, R. D. 2- 
Dimensional crystals of streptavidin on biotinylated lipid layers and

their interactions with biotinylated macromolecules. Biophys. J. 1991,

59, 387-396. 